\title{
Mot en nasjonal delprøve i medisinstudiet
}

\author{
En nasjonal delprøve i medisinstudiet planlegges gjennomført første gang i vårsemesteret 2017. Prøven vil \\ gi grunnlag for økt samordning av innholdet i studiet og bidra til kvalitetsutvikling.
}

I 2014 bestilte dekanene ved de fire medisinske fakultetene en utredning av en nasjonal prøve. Det nasjonale utdanningsmøtet i medisin opprettet i mars 2015 en arbeidsgruppe hvor mandatet var å utarbeide en skriftlig digital delprøve i klinisk resonnement i studiets siste semester. Det har siden kommet utdanningspolitiske ønsker om kvalitetssikring og en sterkere samordning mellom studier (1).

En viktig begrunnelse for delprøven i medisin er at den skal kunne gi studentene informasjon om deres faglige nivå og samtidig gi fagmiljøene en mulighet til å sammenligne prestasjoner på tvers av studiesteder. Arbeidsgruppen har i et forprosjekt vurdert administrative og utdanningsfaglige forhold og laget en plan for hvordan prøven best mulig kan utformes og gjennomføres. Dekanene ble i desember 2015 enige om å gå videre med å utvikle en nasjonal delprøve. Hensikten med denne artikkelen er å formidle hvilke vurderinger som er gjort.

\section{Inspirasjon fra utlandet}

En rekke land har innført nasjonale prøver i medisinstudiet, både sertifiserende for å få lisens, som i USA, men også formative prøver, slik som progresjonstester i Nederland (2). Den norske testen vil ikke være sertifiserende, men vil kunne gi grunnlag for samarbeid mellom studiestedene for gjensidig kvalitetsutvikling og -sikring.

\section{RAMME 1}

Nasjonal delprøve i medisin

- Første pilot planlegges gjennomført tidlig våren 2017

- Siste semester ved studiestedene i Norge

- Utvalgte fagområder i piloten er kardiologi, thoraxkirurgi, gastroenterologi, gastrokirurgi, nefrologi og urologi. Spørsmålene skal ha en allmennmedisinsk vinkling

- Oppgaveformatet i piloten vil være en kombinasjon av ett-beste-svar-flervalgsoppgaver $(75 \%)$ og sekvensielle oppgaver (25\%)

- Prøvetid: 4 timer

- Antall oppgaver: 120 spørsmål

- Vurdering: Automatisert skriftlig tilbakemelding til alle studenter i form av en poengskår etter kvalitetssikret sensur

- Sensorveiledning: Alle oppgaver skal ha fasit med forklaring for senere læring

\section{Klinisk resonnement}

Nasjonal delprøve i medisin skal teste kompetanse i klinisk resonnement. Ideelt sett burde resonnement i klinisk sammenheng bedømmes der kandidaten møter en reell pasient. En slik tilnærming ville være svært ressurskrevende, og det er lagt som føring at prøven skal være digital. Det er vist at skår ved den skriftlige progresjonstesten er sterkt korrelert med tester for klinisk resonneringsevne (3).

\section{Oppgaveformat}

Vi har valgt å basere oppgaveformatet på det som praktiseres internasjonalt. Valgte svaroppgaver, med flervalgsoppgaver som vanligste format, benyttes på andre nasjonale

\section{«Oppgavene må reflek- tere et kompetansenivå som forventes av en nyutdannet lege»}

prøver $(4,5)$. Oppgavetypen med ett-bestsvar har vist seg svært anvendelig i medisinske fag og har høy reliabilitet. Slike oppgaver har en vignett, et klart formulert spørsmål med ett riktig svar og et varierende antall distraktorer. Det riktige svaret skal være klart bedre enn andre svaralternativer. Oppgavene må være valide med hensyn til tematikk, og oppgavesettet må teste bredden i fagområdet. Oppgaveformatet er brukt ved Universitetet i Oslo og Norges teknisk-naturvitenskapelige universitet og kommer til å bli brukt i nasjonal delprøve.

Sekvensielle valgte svaroppgaver gir mulighet til å følge en sykehistorie og få nye spørsmål etter hvert som kasuistikken utvikler seg. Slike oppgaver består av en vignett og ett spørsmål med påfølgende supplerende vignetter og nye spørsmål. Sekvensielle oppgaver etterligner det kliniske resonnementet, men ved en slik oppgavetype er det avgjørende at det ikke etableres følgefeil. Det er lagt opp til å ha en andel sekvensielle oppgaver på nasjonal delprøve for å vinne mer erfaring med oppgavetypen.

Konstruerte svaroppgaver, hvor studenten selv formulerer et svar på et spørsmål med egne ord i fritekst, gir studenten mulighet til å bygge opp et resonnement. Slike oppgaver har imidlertid betydelige ulemper og vil derfor ikke benyttes. Oppgavene er vanskelig å skåre på en reliabel måte, og sensuren er tidkrevende. Det tar dessuten lang tid å besvare slike oppgaver, noe som gjør at kun en relativt liten del av pensum testes (6). Med unntak av Canada benytter ingen av de mest kjente etablerte nasjonale eksamenene slike oppgaver $(5,7,8)$.

\section{Kvalitetssikring av oppgaver}

Systemer for utvikling, kvalitetssikring og vedlikehold av oppgaver er viktige for å sikre at delprøven holder høy kvalitet. Testbetingelser og faglige forutsetninger må være så like som mulig, og det må derfor etableres konsensus om hva en norsk nyutdannet lege bør kunne innenfor prøvens ulike fagområder. Det eksisterer ikke detaljerte læringsutbyttebeskrivelser på tvers av medisinstudiene, og nasjonale fagkomiteer med representanter fra hvert fakultet vil være en mekanisme for å sikre tilstrekkelig faglig forankring og dekning for spørsmål i studieplanene.

Komiteene skal utarbeide oppgaver, som så blir gjenstand for ekstern fagfellevurdering. Oppgavene må reflektere et kompetansenivå som forventes av en nyutdannet lege og skal kvalitetssikres ved at en yngre lege eller allmennlege går igjennom foreslåtte oppgaver. Kommentarer fra fagfeller må vurderes av fagkomiteen før oppgaven blir en del av oppgavesettet.

\section{Kvalitetssikring av tilbakemelding} En viktig del av kvalitetssikringen vil skje etter at prøven er gjennomført og før endelig tilbakemelding foreligger. Studentene skal gis mulighet til å komme med tilbakemelding på enkeltspørsmål. En egen komité vil analysere resultater og kvalitetssikre tilbakemeldingen til studentene om testresultater. Gjennom å samle nok oppgaver i en database kan det etter hvert genereres prøver uten å supplere med mange nye spørsmål for hver gjennomføring.

Oppgaver som viser seg å ha fungert dårlig, vil lukes ut av oppgavedatabasen eller endres og kvalitetssikres på nytt. Eldre oppgaver skal kvalitetssikres før de gjenbrukes. Resultatene fra prøven vil ikke komme i form av graderte karakterer, men som en poengskår og referanseverdier, og prøven er planlagt som et obligatorisk arbeidskrav i studiet.

\section{Tidspunkt og omfang}

Prøven må i minst mulig grad komme i veien for ordinært studieopplegg. Derfor vil prøven gjennomføres tidlig i siste semester, i god tid før studiestedenes egne avsluttende eksamener. For å sikre at prøven har høyest mulig 
reliabilitet og validitet bør antall oppgaver være så høyt som mulig. Det planlegges at nasjonal delprøve første gang vil gjennomføres over fire timer med 120 spørsmål. Det kan være aktuelt å justere tidsmessig omfang og antall spørsmål på sikt. For å sikre at prøven har høy kvalitet over tid vil det være viktig med gode og grundige evalueringer. Tilbakemelding fra studentene er essensielt for å forstå hvordan prøven påvirker deres studiehverdag og innsatsen de legger i prøven, slik at den passer inn i de eksisterende studieplanene på en best mulig måte.

\section{Studenters perspektiv}

Studenter har vært involvert i prosessen og er tydelig på at det ikke er ønskelig med graderte karakterer på nasjonal delprøve, grunnet frykt for at prøven vil bli avgjørende for hvem som får jobb etter studiet (9). Det er likevel viktig at prøven gir noe tilbake til kandidaten, og den enkelte student vil derfor gis en tilbakemelding om hvordan de gjør det både på prøven og i forhold til andre som tar prøven. Det er viktig at prøven ikke blir en ekstrabelastning i tillegg til ordinært studium, men snarere en arena for faglig utvikling som gir studentene innsikt i eget kunnskapsnivå. Resultatene fra prøven vil gjøres tilgjengelig for studiestedene slik at de kan vurdere hvordan deres studenter skårer på prøven, og hvordan de ut fra det vil gjøre eventuelle justeringer i sin studieplan.

\section{Samordning og kvalitetsutvikling}

Denne artikkelen viser noen av vurderingene som er gjort for å løse tekniske, administrative og faglige utfordringer knyttet til etableringen av en nasjonal delprøve. Ytterligere informasjon om prosjektet finnes på en egen nettside (10). Det er særlig to viktige gevinster ved en nasjonal delprøve. Ved at hvert studiested kan vurdere hvordan deres studenter skårer på hele og deler av prøven, sammenlignet med andre studiesteder, vil prøven bli et verktøy for målrettet kvalitetsutvikling. Det gjør prøven til et viktig redskap for studiestedene til å forstå hvor studiene må forbedres, og hvor studentene har godt læringsutbytte. Dessuten er det ønskelig med en viss overordnet samordning av studiene i Norge, samtidig som de ulike studiestedenes profil bevares slik at de kan ivareta spesielle regionale behov.
Vi takker de øvrige medlemmene i prosjektgruppen, Eirik Dalheim, Elin Holm, Kristin Walter og Marte Laugen, for deres bidrag i arbeidet.

Eivind A. Valestrand
Tobias S. Slørdahl
Anders Bærheim
Henrik Schirmer
Stine Andersen
Hanne-Guro Aabelvik
Jan Frich
jan.frich@medisin.uio.no

Eivind A. Valestrand (f. 1989) er medisin- og forskerlinjestudent ved Universitetet i Bergen, der han har hatt flere tillitsverv. Han er studentrepresentant i prosjektgruppen for nasjonal delprøve i medisin.

Forfatter har fylt ut ICMJE-skjemaet og oppgir ingen interessekonflikter.

Tobias S. Slørdahl (f. 1982) er ph.d., postdoktor og førsteamanuensis II ved Institutt for kreftforskning og molekylærmedisin ved Norges teknisk-naturvitenskapelige universitet og lege i spesialisering ved Medisinsk klinikk, St. Olavs hospital. Han er medlem av prosjektgruppen for nasjonal delprøve i medisin.

Forfatter har fylt ut ICMJE-skjemaet og oppgir ingen interessekonflikter.

Anders Bærheim (f. 1948) er professor i allmennmedisin ved Institutt for global helse og samfunnsmedisin, Universitetet i Bergen, og medlem av prosjektgruppen for nasjonal delprøve i medisin.

Forfatter har fylt ut ICMJE-skjemaet og oppgir ingen interessekonflikter.

Henrik Schirmer (f. 1960) er professor ved Institutt for klinisk medisin, Det helsevitenskaplige fakultet, Universitetet i Troms $\varnothing$ - Norges arktiske universitet, og overlege ved Hjertemedisinsk avdeling, Universitetssykehuset NordNorge. Han er medlem av prosjektgruppen for nasjonal delprøve i medisin.

Forfatter har fylt ut ICMJE-skjemaet og oppgir ingen interessekonflikter.

Stine Andersen (f. 1991) er medisinstudent ved Universitetet i Troms $\varnothing$ - Norges arktiske universitet og studentrepresentant i prosjektgruppen for nasjonal delprøve i medisin.

Forfatter har fylt ut ICMJE-skjemaet og oppgir ingen interessekonflikter.
Hanne-Guro Aabelvik (f. 1981) er rådgiver ved Studieseksjonen, Det medisinske fakultet, Universitetet i Oslo, og administrativ koordinator og medlem av prosjektgruppen for nasjonal delprøve i medisin.

Forfatter har fylt ut ICMJE-skjemaet og oppgir ingen interessekonflikter.

Jan Frich (f. 1970) er professor ved Institutt for helse og samfunn, Det medisinske fakultet, Universitetet i Oslo og overlege ved Nevrologisk avdeling, Oslo universitetssykehus. Han er prosjektleder for nasjonal delprøve i medisin. Forfatter har fylt ut ICMJE-skjemaet og oppgir ingen interessekonflikter.

\section{Litteratur}

1. Nasjonalt organ for kvalitet i utdanningen. Nasjonal deleksamen. http://nokut.no/no/Universitetog-hoyskoler/Kvalitetssikring-og--utvikling/ Nasjonal-deleksamen/ (17.1.2016)

2. van der Vleuten CPM, Verwijnen GM, Wijnen WHFW. Fifteen years of experience with progress testing in a problem-based learning curriculum. Med Teach 1996; 18: 103-09.

3. Boshuizen HPA, van der Vleuten CPM, Schmidt HG et al. Measuring knowledge and clinical reasoning skills in a problem-based curriculum. Med Educ 1997; 31: 115-21.

4. United States Medical Licensing Examination. http://usmle.org/ (1.1.2016).

5. Chenot JF. Undergraduate medical education in Germany. Ger Med Sci 2009; 7: Doc02.

6. Downing SM. Written tests - constructed-response and selected-response formats. I: Downing SM, Yudkowsky R, red. Assessment in health professions education. New York, NY: Routledge, 2009: 149-84.

7. Guttormsen S, Beyeler C, Bonvin R et al. The new licencing examination for human medicine: from concept to implementation. Swiss Med Wkly 2013 143: w13897.

8. Haist SA, Katsufrakis PJ, Dillon GF. The evolution of the United States Medical Licensing Examination (USMLE): enhancing assessment of practicerelated competencies. JAMA 2013; 310: 2245-6.

9. Engen $\emptyset \mathrm{B}$. Nmf sier nei til karakterer på nasjonal eksamen. Dagens Medisin 30.3.2015

http://dagensmedisin.no/artikler/2015/03/30/nmfsier-nei-til-karakterer-pa-nasjonal-eksamen/ (15.1.2016)

10. Nasjonal delprøve i medisin. http://med.uio.no/om/ prosjekter/nasjonal-delprove-medisin/ (8.2.2016).

Mottatt 22.1. 2016, første revisjon innsendt 9.2. 2016, godkjent 11.2. 2016. Redaktør: Ketil Slagstad.

Publisert først på nett. 